\title{
Pharmacognosy \\ Ethnobotany, ecology, pharmacology, and chemistry of Anredera cordifolia (Basellaceae): a review
}

\author{
Thainara Marcotto Alba ${ }^{1,4,5}$, Carla Maria Garlet de Pelegrin ${ }^{2}$ \& Andréa Michel Sobottka ${ }^{1,3}$
}

\begin{abstract}
The potential of a plant with medicinal and nutritional properties, Anredera cordifolia, is reviewed. Its common names include "Bertalha" and "folha gorda" and it is popularly used for wound healing and against fungal infections and other types of infection. Its pharmacological properties have been widely investigated and acknowledged, especially with regard to its antibacterial activity, which improves the healing of wounds infected by Staphylococcus aureus, and to its antifungal activity against Candida albicans. It is an unconventional food plant, with leaves and aerial tubers used as food prepared in varied ways. It is also considered an invasive plant in several countries and thus classified as a weed. Its characteristics of a Brazilian native plant, with proven medicinal properties and unconventional use as food, underlie our study on its ecology and botanical classification, as well as the pharmacological assays and screening of chemical constituents.

Key words: antimicrobial activity, invasive plants, medicinal plants, phytochemistry, unconventional food plant.

\section{Resumo}

O potencial de uma planta com propriedades medicinais e alimentícias, Anredera cordifolia, é abordado nesta revisão. Esta planta é conhecida no Brasil por "bertalha" ou "folha gorda", sendo utilizada popularmente para o tratamento de feridas, fungos e infecções. Suas propriedades farmacológicas têm sido amplamente investigadas e confirmadas, com destaque para a ação antibacteriana, melhorando a cicatrização de feridas infeccionadas por Staphylococcus aureus, e ação antifúngica contra Candida albicans. É uma hortaliça não convencional, sendo suas folhas e bulbos aéreos consumidos na alimentação sob diversas formas. Também faz parte da flora invasora de vários países, e classificada popularmente como "erva daninha". Suas características de planta nativa brasileira, com reconhecido efeito medicinal e uso alimentício não convencional, conduzem as nossas investigações sobre ecologia e classificação botânica, ensaios farmacológicos e rastreio de constituintes químicos realizados com essa espécie. Palavras-chave: atividade antimicrobiana, plantas invasoras, plantas medicinais, fitoquímica, planta alimentícia não convencional.
\end{abstract}

\section{Introduction}

The traditional medicine approaches to the prevention and diagnosis of diseases, improvement of physical and mental functions, and maintenance of health also include medicinal plants (OMS 2013). These plants are used in different formulations (infusions, ointments, syrups, among others) for the treatment and cure of diseases, and they are considered to be an age-old tradition in healthcare (Veiga Junior et al. 2005; Oliveira et al. 2007).

In Brazil, a country rife with biodiversity, species regarded as medicinal tend to be highly estimated. For example, 89 new monographs on plants and the review of another 58 (Brasil 2017) were included in the second supplement of Brazilian Pharmacopeia 5. Even though plants

\footnotetext{
${ }^{1}$ Universidade de Passo Fundo - UPF, Inst. Ciências Biológicas, Prog. Pós-graduação em Ciências Ambientais, Rod. BR-285, km 292, 99052-900, Passo Fundo, RS, Brasil.

${ }^{2}$ Universidade Federal da Fronteira Sul - UFFS, Campus Cerro Largo, Licenciatura em Ciências Biológicas, R. Jacob Reinaldo Haupenthal 1.580, Bairro São Pedro, 97900-000, Cerro Lago, RS, Brasil.

${ }^{3}$ Universidade de Passo Fundo - UPF, Inst. Ciências Biológicas, Curso de Farmácia, Rod. BR-285, km 292, 99052-900, Passo Fundo, RS, Brasil.

${ }^{4}$ ORCID: <https://orcid.org/0000-0002-8616-6153>

${ }^{5}$ Author for correspondence: 171902@upf.br
} 
are broadly investigated in Brazil, it is widely known that many gaps still exist, especially in the case of angiosperms (Stehmann \& Sobral 2017). Many plant species continue to be used in popular medicine without proven medicinal effects and despite the lack of knowledge of their possible undesirable effects (Heinzmann \& Barros 2007).

With irrefutable medicinal properties Anredera cordifolia (Ten.) Steenis stands out in the treatment of wounds, fungal infections, and other types of infections (Heisler et al. 2012). Anredera cordifolia, which belongs to the family Basellaceae, is of great interest, not only because of its pharmacological properties, but also because of its high nutritional value.

The family Basellaceae includes genera without fleshy to succulent tendrils, herbaceous plants, or occasionally woody plants and erect plants. These perennial plants have subterranean and aerial tubers, with simple leaves without stipules, and with succulent, herbaceous, or lignified stems (Erikson 2007; Pellegrini \& Imig 2019).

Basellaceae has a pantropical distribution of the genera Anredera Juss., Basella L., Tournonia Moq., and Ullucus Caldas. In Brazil, Anredera cordifolia and Anredera tucumarensis (Lillo \& Hauman) Sperling are native species (Pellegrini \& Sakuragui 2017), and the genus Basella was introduced in Brazil (Souza \& Lorenzi 2012).

Anredera is the largest genus of this family with approximately 12 species, with broader diversity in the Andean region. It differs from the genus Basella because of its inflorescences with thin rachises (vs. fleshy ones in Basella), connate sepals (free ones in Basella), stalked and fragrant flowers (odorless and sessile in Basella), and spheroidal and echinate pollen (cuboidal and reticulate in Basella) (Erikson 2007; Pellegrini \& Sakuragui 2017).

Native but not endemic to Brazil, Anredera cordifolia is popularly known as "bertalha, basela, folha-gorda, or trepadeira-mimosa" (Pellegrini \& Imig 2019; Souza \& Lorenzi 2012). In Indonesia and neighboring regions, it is known as "binahong" (Sumartiningsih 2011), whereas in Australia it is called "madeira vine" (Vivian-Smith et al. 2007). In Argentina, it is known as "zarza-parilla" (Scarpa 2004) and "papa santa" (Hilgert 2001).

It is considered an unconventional food plant, as its leaves and aerial tubers are eaten in varied forms (Kelen et al. 2015), serving as an excellent source of proteins and fibers (Martinevski et al.
2013). The leaves are used for making breads (Martinevski et al. 2013) and the tubers can be eaten either cooked or fried (Kinupp \& Lorenzi 2014). It is also grown as an ornamental plant (Souza \& Lorenzi 2012) e.g., as hedge (Mogale et al. 2019). This species has a wide tropical distribution in America, Australia, China, Malaysia, Southern Pacific Islands, and Africa (Rasingam \& Lakshminarasimhan 2012). In Brazil, it is found in the northeast (Bahia, Ceará, and Pernambuco); midwest (Mato Grosso do Sul); southeast (Espírito Santo, Minas Gerais, Rio de Janeiro, and São Paulo); and south (Paraná, Rio Grande do Sul, and Santa Catarina) (Pellegrini \& Imig 2019).

In Brazil, this species has fallen into disuse (Kinupp et al. 2004), and it has been underinvestigated in pharmacological studies. In other countries such as Indonesia, many studies have been conducted, corroborating its pharmacological potential. A literature review was performed, demonstrating the medicinal and nutritional properties of this species, as well as its potential for the development of pharmaceuticals.

\section{Materials and Methods}

A literature search was conducted in Scielo, Scopus, Web of Science, Medline, and BioOne databases, in addition to books and other sources such as botanical gardens around the world. The scientific names (Anredera cordifolia and Bossingaultia gracilis) were used as descriptor, with no restriction imposed on year of publication. The species Anredera cordifolia was photographed in the city of Sarandi-RS $\left(27^{\circ} 58^{\prime} 11,9064\right.$ 'S $52^{\circ} 54^{\prime} 29.7864^{\prime \prime} \mathrm{W}$ ) and was identified by the curator Prof. Cristiano Roberto Buzatto. The exsiccates are stored under the number: RSPF 14413, at the Herbarium RSPF which is linked to the Zoobotanic Museum Augusto Ruschi (MUZAR), from the Institute of Biological Sciences of the University of Passo Fundo (UPF).

\section{Results and Discussion}

Botany, ecology, and chemical

and biological control

Anredera cordifolia is a climbing plant, found in forest borders, on fences along roads, and in plots of land at $1,000 \mathrm{~m}$ to 2,000 $\mathrm{m}$ (Rasingam \& Lakshminarasimhan 2012). It is also seen in anthropized regions, such as in vacant lots in urban areas (Fig. 1a) (Imig et al. 2015), as it is considered to be ruderal (Pellegrini \& Sakuragui 2017). In 
Brazil, more specifically in the state of Rio Grande do Sul, it is found on the borders of rainforests and in the Pampa region (Souza \& Lorenzi 2012; Pellegrini \& Sakuragui 2017).

This species grows in well-lit environments and has fleshy tubers that may be seen in the nodes of aerial petioles (Fig. 1b) (Vivian-Smith et al. 2007). Its leaves are cordate to ovate (Boyne et al. 2013) very fleshy, dark green, shiny, and rarely elliptical (Imig et al. 2015; Pellegrini \& Sakuragui 2017). It is characterized by white, pendent, and fragrant inflorescences (Souza \& Lorenzi 2012) such as racemes or panicles, either axillary or terminal (Fig. 1c). The flowers are perfect with triangular to broadly ovate bracteoles, the sepals are broadly ovate to broadly elliptical, the petals are uniform, patent, elliptical to obovate, white or greenish white, with trifid style and capitate stigma. The fruit is a patent brown achene (Pellegrini \& Sakuragui 2017).

Anredera cordifolia differs from Anredera tucumarensis because of the presence of aerial tubers, membranous leaves with no involute margins in sicco, poorly apparent secondary veins, connate bracteoles, uniform petals larger than the sepals, and trifid style (Erikson 2007; Pellegrini $\&$ Sakuragui 2017). In terms of leaf anatomy, the epidermis of $A$. cordifolia lacks trichomes and the stomata have two to three subsidiary cells on both leaf surfaces. The mesophyll has mucilage cells, calcium oxalate, narrow vascular bundles, and no sclerenchyma (Boyne et al. 2013). Chromosome analysis revealed that $A$. cordifolia subspecies gracilis has sexual reproduction, bearing viable fruits, with $2 \mathrm{n}=24$ chromosomes. Anredera cordifolia subspecies cordifolia only reproduces vegetatively, with $2 \mathrm{n}=36$ chromosomes (Xifreda et al. 2000).

Widely known in Portugal, this species was introduced there in 1961, when it was regarded as a species that would be problematic in the future (Silva et al. 2015). Anredera cordifolia includes highly invasive lianas, as a result of phenotypic plasticity (Pintó-Marijuan \& Munné-Bosch 2013) and it is therefore classified as an "invasive plant" (Kinupp et al. 2004) or "weed" (Palmer et al. 2010). It is known as an "alien plant" in Australia, China, and Africa (Jian et al. 2008; Baard \& Kraaij 2014; Byrne et al. 2017; Gao et al. 2018; Shen et al. 2018), where sustained effort has been put in for its control (Van Driesche et al. 2010).

In China, it is found in vacant lots, orchards, forests, roads, and conservation units, and it has been reported to invade crops such as banana, lemon, and orange (Shen et al. 2017; Zhu et al. 2018). In abandoned lands with yellow soil, there are a large number of vines as compared to other species, and these vines eventually reduce the number of seedlings, inhibiting restoration and ecological succession (Haitan et al. 2011). Anredera cordifolia is a threat to several plant communities (Vivian-Smith et al. 2007) and it is also harmful to riparian vegetation (Floyd 1989).

In New South Wales, Australia, it has been a threat to the local biodiversity, requiring control measures (Downey et al. 2010). A study undertaken in Argentina revealed that a beetle belonging to the family Chrysomelidae, Plectonycha correntina Lacordaire, may be used as a biocontrol agent against $A$. cordifolia (Cagnotti et al. 2007; Westhuizen 2011). This species is host to Dichotomophthora, they are used for the biological control of $A$. cordifolia, as they cause leaf abscesses, spots, and seed rot (Marin-Felix et al. 2019). Regarding chemical control, Anredera cordifolia is tolerant of glyphosate and fluroxypyrmeptyl treatments in some cases (Waryszak et al. 2018).
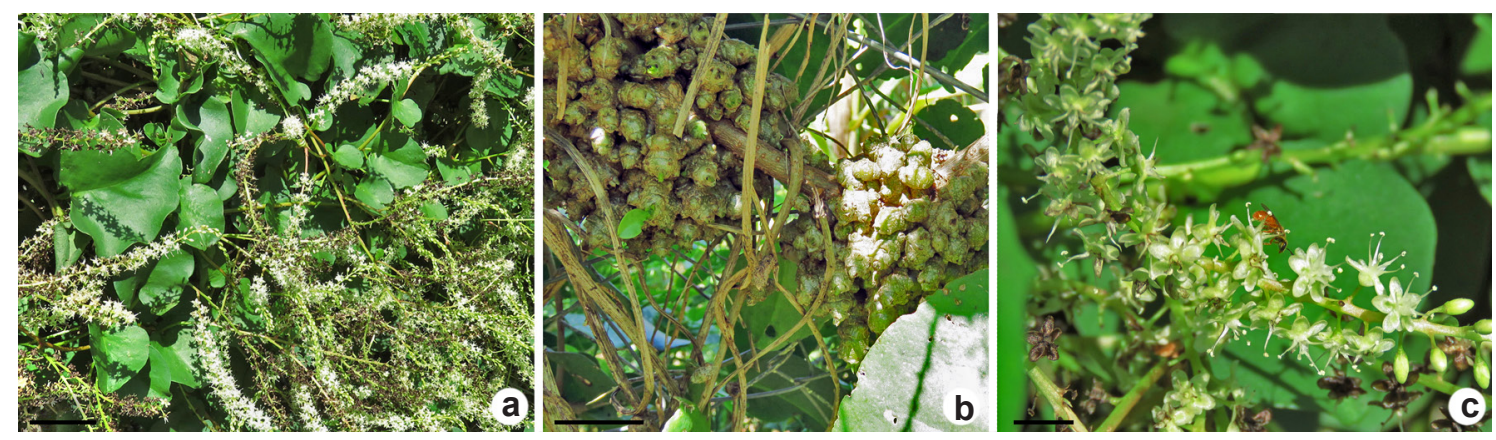

Figure 1 - a-c. Anredera cordifolia - a. aerial parts; b. tubers; c. flowers. Scale bars: a. 21 mm; b. 10 mm; c. 4 mm. 
Ethnobotany

In several regions around the world, $A$. cordifolia has been described and used as a medicinal plant. Studies carried out in Asia, especially in Indonesia and neighboring regions, used ointments and gels made from extracts of the plant, which demonstrated antibacterial activity (Zulfa et al. 2017), and efficacy in wound healing (Istyastono \& Yuliani 2016; Shrivastav et al. 2018) including wounds infected by Staphylococcus aureus (Paju et al. 2013). The gel aided in the healing of burns (Istyastono \& Yuliani 2016; Prasetyo \& Herihadi 2013) and in the reduction of diabetic ulcers in rats (Kintoko \& Desmayanti 2016). In Malaysia, A. cordifolia is used to treat diabetes, liver diseases, hypertension, hypercholesterolemia, blood clots, and mental and physical stress (Astuti et al. 2011). Moreover, in Thailand, its leaves and stalks are used by parturients as postpartum tonic (Panyaphu et al. 2011; Fitriana et al. 2018) and for milk letdown, its leaves are cooked with chicken (Srithi et al. 2012).

In Africa, the plant is used as a medicinal agent (Magwede et al. 2018) for the treatment of sexually transmitted infections (Tshikalange et al. 2005) such as for the treatment of gonorrhea, in which the seeds are used (Mulaudzi et al. 2015; Mulia et al. 2017).

In Latin America, it is broadly used as a medicinal plant as well. In Colombia, it is used to treat diabetes, fractures, conjunctivitis, and cough (Bussmann et al. 2018). In Uruguay, it is utilized against poisonings and as eye wash (Paz et al. 1995). In northwestern Argentina, its stems are cut into thick slices and placed on the patient's forehead to treat headaches, and on the cheeks to treat toothaches (Hilgert 2001). A mixture containing a handful of leaves in 2 liters of water is drunk as tea for nine days in a row to treat amenorrhea (Scarpa 2004). In addition, A. cordifolia is used against cough and ocular inflammatory disease in Argentina (Paccard 1905).

In Brazil, the plant is used as a medicinal herb, mainly in the southern region (Zank \& Hanazaki 2012). For instance, in the state of Rio Grande do $\mathrm{Sul}$, its fresh leaves are used to treat burns, wounds, onychomycosis, and insect bites (Heisler et al. 2012). In a village of artesanal fisherman, also in Rio Grande do Sul, in the Biological Reserve of Lami, it is used as a medicinal herb and as food source, its is leaves anda stalks are used as aphrodisiac, and also against skin lesions and circulatory system disordes (Baptista et al. 2013).

\section{Pharmacological assays}

\section{In vitro}

Several studies have shown promising results against microorganisms (Tshikalange et al. 2005; Yan et al. 2011; Garmana et al. 2014; Souza et al. 2014). The ethanolic extract obtained from the stem demonstrated antifungal activity against Candida albicans (Kumalasari $\&$ Sulistyani 2011). The infusion of $A$. cordifolia leaves at high concentrations inhibited the growth of Porphyromonas gingivalis and Prevotella intermedia (Maharani et al. 2018). The n-hexane, ethyl acetate and ethanolic extracts of $A$. cordifolia leaves showed activity against Mycobacterium tuberculosis strains, and the hexane extract showed better activity (Pitaloka \& Sukandar 2018).

Aqueous and chloroform extracts obtained from the roots inhibited the growth of several bacteria, including Staphylococcus and Pseudomonas, in a screening in Africa in which six medicinal species were tested (Tshikalange $e t$ al. 2005). The growth of Streptococcus mutans was inhibited by ethanolic extract of leaves (Rimporok et al. 2015). Bacillus cereus, Salmonella enteritidis (Rahmawati \& Bintari 2014), Escherichia coli, Staphylococcus aureus, Pseudomonas aeruginosa and Bacillus subtilis (Paz et al. 1995), also had their growth inhibited by aqueous leaf extracts of the plant. On the other hand, the methanolic extract prepared from $A$. cordifolia leaves did not inhibit the growth of Staphylococcus aureus, Enterococcus faecalis, Escherichia coli, and Pseudomonas aeruginosa (Amertha et al. 2012).

A phytotherapeutic product with $A$. cordifolia seeds and other plants was efficient in inhibiting the growth of Staphylococcus aureus, Klebsiella pneumoniae, and Neisseria gonorrhoeae, and also in inhibiting HIV-1 reverse transcriptase, without causing mutagenic effects (Mulaudzi et al. 2015).

Besides the antimicrobial activity of $A$. cordifolia, the literature describes a considerable number of pharmacological studies on this species. Promising effects of leaf extracts have been described against cervical cancer (Yuliani et al. 2015), and reduction of a tumor necrosis factor and other inflammatory mediators in macrophage lines (Laksmitawati et al. 2017). Ethanolic leaf extract of A. cordifolia and Centella asiatica L. exhibited anti-inflammatory activity in human red blood cells in a membrane stabilization assay (Sutrisno et al. 2016). Leaf extract microemulsion at $0.5 \%$ also demonstrated antiaging effects (Nazliniwaty et al. 2018). 


\section{In vivo assays}

The literature describes a wide variety of in vivo pharmacological assays with raw extracts and fractions obtained from Anredera cordifolia. The oral administration, in Guinea pig (Cavia cobaya), of $50 \mathrm{mg}$ leaf extract improved immunity and resistance during and after childbirth, also improving the blood parameters and quality of postpartum care (Wijayanti et al. 2016, 2017). Its leaf extract was also efficient in the wound healing of guinea pigs (Miladiyah \& Prabowo 2012) and demonstrated vasodilatory properties in rabbits and toads (Sukandar et al. 2016a).

Tests with Wistar rats revealed that the ethanolic leaf extract of $A$. cordifolia works as an antiobesity medication (Sukandar et al. 2016b), has diuretic effects, and lowers blood pressure (Garmana et al. 2016), total cholesterol, and triglyceride levels (Lestari et al. 2015). Moreover, the ethanolic extract may be used to treat gout, as it reduces serum urate levels (Widyarini et al. 2015; Hendriani \& Sukandar 2016).

Other assays indicated that the ethanolic extract was efficient in the treatment of kidney failure in Wistar rats (Sukandar et al. 2011, 2013), protected against the effects of ethanol on the renal proximal tubular epithelial cells of Sprague-Dawley albino rats (Asmariati et al. 2014). Also, the ethanolic extract exhibited analgesic activity in the "plantar test method" (Yuziani et al. 2014). The administration of ethanolic extract of $A$. cordifolia combined with that of black mulberry (Morus nigra L.) enhanced the lipid profile of rats (Sukandar et al. 2016c), and combined with the extract of Areca catechu L., it reduced the incidence of Ascaridia galli in Gallus gallus domesticus (Prastowo et al. 2017). The administration of $A$. cordifolia to Wistar rats for 3 days reduced cellular inflammation by $5 \%$ and increased fibroblast growth in bruises (Sumartiningsih 2011). A. cordifolia rhizomes contain ancordin, a protein that can inhibit trypsin and stimulate the cellular production of nitric oxide (Chuang et al. 2007).

\section{Toxicity}

Regarding toxic effects, Anredera cordifolia is not toxic to Wistar rats (Salasanti et al. 2014), and it does not have teratogenic effects on them (Sukandar et al. 2014). The cytotoxic, genotoxic, and antimutagenic effects of Boussingaultia gracilis Miers var. pseudobaselloides Bailey were investigated in Salmonella typhimurium (Ames test) and in human lymphocytes (comet assay), and was found to be non-toxic (Yen et al. 2001).

\section{Phytochemistry}

Even though the pharmacological properties of Anredera cordifolia have been widely investigated, reports on the chemical compounds present in its extracts are limited to phytochemical screening, to a study on its volatile constituents, and to some compounds in particular, such as saponins and flavonoids.

Lin et al. (1988) isolated a new triterpenoid sapogenin, elucidated as ethyl $3 \beta$-hydroxy30-noroleana-12,18-dien-29-oate, from Boussingaultia gracilis (A. cordifolia synonym). Their study also describes the isolation of another five sapogenins: larreagenin A, $3 \beta$-hydroxy30-noroleana-12,19-dien-28-oic acid and its ethyl ester, ursolic acid, 28-ethyl hydrogen $3 \beta$-hydroxyolean-12-ene-28,29-dioate.

Other compounds isolated from $A$. cordifolia leaf extracts include 3,5,3',4'-tetrahydroxyflavone (Rahmawati et al. 2013) and the flavonoid 8-glucopyranosyl-4',5,7-trihydroxyflavone (vitexin) (Djamil 2012). Vitexin exhibited antioxidant activity when tested with the 2,2-diphenyl-1-picrylhydrazyl (DPPH) method (Djamil 2012), and demonstrated in vitro $\alpha$-glucosidase inhibitory activity and antidiabetic activity in alloxan-induced mice (Djamil 2012; Djamil et al. 2017). A new method for the extraction of this compound from A. cordifolia leaves, with a non-toxic and environmentally friendly solvent, was proposed (Mulia et al. 2017). Myricetin and morin were detected by high-performance liquid chromatography (HPLC), whereas kaempferol and quercetin were not found in $A$. cordifolia leaves extracts. The concentrations of polyphenols, flavonoids, and flavonols were determined by spectrophotometric methods, but anthocyanidins were not detected (Chao et al. 2014). On the other hand, Yang et al. (2008), in a work with 91 edible species, related the presence of quercetin in shoots of $A$. cordifolia.

The volatile constituents of the aerial parts were analyzed and the major compounds were phytol (15.33\%), alpha-pinene $(9.0 \%)$, and 6,10,14-trimethyl pentadecanone $(6.12 \%)$. In this work vitexin and isovitexin were also isolated (Abou-Zeid et al. 2007). The essential oil was analyzed by GC and GC-MS and 19 compounds were identified. Hydrocarbons were the main constituents (67.7\%) (Souza et al. 2014). 
Lupeol and $\beta$-sitosterol (Basyuni et al. 2017), and ursolic acid (Yuliani \& Istyastono 2013) were detected by thin-layer chromatography (TLC). Using TLC as a support, UV-VIS, and FTIR spectrophotometry, Ekaviantiwi et al. (2013) concluded that ethanolic extracts of leaves might contain $p$-coumaric acid. The presence of saponins was verified by general detection tests (foam formation), using TLC, and also by the analytical method (Astuti et al. 2011). The tests were positive for saponins in all plant parts.

Phytochemical screening was positive for flavonoids, saponins, steroids/terpenoids, and alkaloids (Ekaviantiwi et al. 2013; Rahmawati et al. 2013; Elya et al. 2015; Lestari et al. 2015, 2016; Sukandar et al. 2016c; Pitaloka \& Sukandar 2018). Screening of alkaloids showed also negative results (Kumalasari \& Sulistyani 2011; Garmana et al.
2014; Sukandar et al. 2016b; Kaunang \& Semuel 2017) or positive ones only for Dragendorff's reagent, with negative results for Bouchardat's, Wagner's, and Mayer's reagents (Basyuni et al. 2017). Some authors found negative results in the screening test for tannins (Kumalasari \& Sulistyani 2011; Elya et al. 2015; Lestari et al. 2015, 2016; Sukandar et al. 2016b) whereas some obtained positive results (Ekaviantiwi et al. 2013; Rahmawati et al. 2013; Garmana et al. 2016; Sukandar et al. 2016c; Kaunang \& Semuel 2017; Pitaloka \& Sukandar 2018). Polyphenols (Kumalasari \& Sulistyani 2011; Sukandar et al. 2016b, c; Basyuni et al. 2017; Pitaloka \& Sukandar 2018) and glucoside (Astuti et al. 2011; Elya et al. 2015) were also detected in screening tests. Some studies checked for the presence of quinones but all tests were negative (Garmana et al. 2014; Elya et

Table 1 - Phytochemical screening test results for $A$. cordifolia described in the literature.

\begin{tabular}{|c|c|c|c|c|c|c|c|c|}
\hline Reference & Saponins & $\begin{array}{l}\text { Steroids/ } \\
\text { terpenoids }\end{array}$ & Flavonoids & Alkaloids & Tannins & Polyphenols & Glucosides & Quinones \\
\hline Astuti et al. (2011) & $(+)$ & $(+)$ & ---- & $(+)$ & $\begin{array}{l}--- \\
---\end{array}$ & $\begin{array}{l}--- \\
---\end{array}$ & $(+)$ & $\begin{array}{l}--- \\
---\end{array}$ \\
\hline $\begin{array}{l}\text { Kumalasari \& } \\
\text { Sulistyani (2011) }\end{array}$ & $(+)$ & ---- & $(+)$ & $(-)$ & $(-)$ & $(+)$ & ---- & ---- \\
\hline $\begin{array}{l}\text { Ekaviantiwi et al. } \\
\text { (2013) }\end{array}$ & $(+)$ & $(+)$ & $(+)$ & $(+)$ & $(+)$ & ---- & ---- & ---- \\
\hline $\begin{array}{l}\text { Rahmawati et al. } \\
\text { (2013) }\end{array}$ & $(+)$ & $(+)$ & $(+)$ & $(+)$ & $(+)$ & ---- & ---- & ---- \\
\hline $\begin{array}{l}\text { Garmana et al. } \\
\text { (2014) }\end{array}$ & $(+)$ & $(+)$ & $(+)$ & $(-)$ & ---- & ---- & ---- & $(-)$ \\
\hline Elya et al. (2015) & $(+)$ & $(+)$ & $(+)$ & $(+)$ & $(-)$ & ---- & $(+)$ & $(-)$ \\
\hline $\begin{array}{l}\text { Lestari et al. (2015, } \\
\text { 2016) }\end{array}$ & $(+)$ & $(+)$ & $(+)$ & $(+)$ & $(-)$ & ---- & --- & $(-)$ \\
\hline $\begin{array}{l}\text { Garmana et al. } \\
\text { (2016) }\end{array}$ & $(+)$ & $(+)$ & $(+)$ & ---- & $(+)$ & ---- & ---- & ---- \\
\hline $\begin{array}{l}\text { Sukandar et al. } \\
\text { (2016b) }\end{array}$ & $(+)$ & $(+)$ & $(+)$ & $(-)$ & $(-)$ & $(+)$ & ---- & $(-)$ \\
\hline $\begin{array}{l}\text { Sukandar et al. } \\
\text { (2016c) }\end{array}$ & $(+)$ & $(+)$ & $(+)$ & $(+)$ & $(+)$ & $(+)$ & ---- & $(-)$ \\
\hline $\begin{array}{l}\text { Basyuni et al. } \\
\text { (2017) }\end{array}$ & $(+)$ & $(+)$ & ---- & $\begin{array}{l}*(+) \\
* *(-)\end{array}$ & ---- & $(+)$ & ---- & ---- \\
\hline $\begin{array}{l}\text { Kaunang \& Semuel } \\
\text { (2017) }\end{array}$ & $(+)$ & $(-)$ & $(+)$ & $(-)$ & $(+)$ & ---- & ---- & ---- \\
\hline $\begin{array}{l}\text { Pitaloka \& } \\
\text { Sukandar (2018) }\end{array}$ & $(+)$ & $(+)$ & $(+)$ & $(+)$ & $(+)$ & $(+)$ & ---- & $(+)$ \\
\hline
\end{tabular}

$(+)=$ positive tests; $(-)=$ negative tests; $*(+)=$ with Dragendorf's reagent; $* *(-)=$ with Mayer, Bouchardat and Wagner's reagents. 
al. 2015; Lestari et al. 2015, 2016; Sukandar et al. 2016b, c). However, Pitaloka \& Sukandar (2018) found positive results for quinones. Table 1 lists the articles and results obtained from phytochemical screening tests with $A$. cordifolia extracts.

Therefore, vitexin, isovitexin, myricetin, morin, 3,5,3',4'-tetrahydroxyflavon and ursolic acid; larreagenin A, 3 $\beta$-hydroxy-30-noroleana12,19-dien-28-oic acid and its ethyl ester, 28-ethyl hydrogen $3 \beta$-hydroxyolean-12-ene-28,29-dioate, and ethyl 3 $\beta$-hydroxy-30-noroleana-12,18-dien-29oate were isolated from $A$. cordifolia extracts. The probable presence of $p$-coumaric acid, lupeol, and $\beta$-sitosterol was verified by TLC using a reference standard.

The present review demonstrates the main uses, as well as the medicinal and nutritional properties, of $A$. cordifolia. This plant is an invasive species in several countries, and the problems caused by it and its management should be addressed. A. cordifolia is a promising medicinal plant, as several pharmacological assays corroborate its efficacy, especially its antimicrobial activity. Some flavonoids, such as vitexin, isovitexin, morin, and myricetin, in addition to sapogenins such as ursolic acid were isolated from its extracts. Phytochemical screening evidenced the presence of metabolites such as alkaloids, flavonoids, saponins, steroids, and terpenoids. The isolation and identification of other chemical compounds and the characterization of a marker for this species are essential for the development of a phytotherapeutic agent from $A$. cordifolia extracts.

\section{Acknowledgments}

The authors acknowledgment the graduate Postprogram in Environmental Sciences at the University of Passo Fundo (UPF) and Foundation University of Passso Fundo (FUPF) for the scholarship.

\section{References}

Abou-Zeid AHS, Soliman FM, Sleem AA \& Mitry MNR (2007) Phytochemical and bio-activity investigations of the aerial parts of Anredera cordifolia (Ten.) Steenis. Bulletin of the National Research Centre (Cairo) 32: 1-33.

Amertha IBPM, Soeliongan S \& Kountul C (2012) In vitro inhibition zone test of binahong (Anredera cordifolia) towards Staphylococcus aureus, Enterococcus faecalis, Escherichia coli, and Pseudomonas aeruginosa. Indonesian Journal of Biomedical Sciences 6: 30-34.
Asmariati YD, Busman H, Susantiningsih T \& Susianti (2014) Protective effect of binahong leaf (Anredera cordifolia (Ten.) Steenis) Extract against ethanolinduced proximal tubule renal histopatological features of sprague dawley. Medical Journal of Lampung University 3: 168-177.

Astuti SM, Sakinah MA, Andayani RB \& Risch A (2011) Determination of saponin compound from Anredera cordifolia (Ten.) Steenis plant (Binahong) to potential treatment for several diseases. Journal of Agricultural Science 3: 224-232.

Baard JA \& Kraaij T (2014) Alien flora of the Garden Route National Park, South Africa. South African Journal of Botany 94: 51-63.

Baptista MM, Ramos MA, De Albuquerque UP, Coelhode-Souza G \& Ritter MR (2013) Traditional botanical knowledge of artisanal fishers in southern Brazil. Journal of Ethnobiology and Ethnomedicine 9: 1-16.

Basyuni M, Ginting PYAB \& Lesmana I (2017) Phytochemical analysis of Binahong (Anredera cordifolia) leaves extract to inhibit In Vitro growth of Aeromonas hydrophila. AIP Conference Proceedings 1904: 020072-1-5.

Brasil - Agência Nacional de Vigilância Sanitária (2017) Farmacopeia brasileira. Avaliable at $<$ http:// portal.anvisa.gov.br/documents/33832/259143/ Segundo+Suplemento+FB+5/9cfb1239-875c-4a778741-b59416684d29>. Access on 02 May 2019.

Boyne RL, Osunkoya OO \& Scharaschkin T (2013) Variation in leaf structure of the invasive Madeira vine (Anredera cordifolia, Basellaceae) at different light levels. Australian Journal of Botany 61: 412417.

Bussmann RW, Paniagua Zambrana NY, Romero C \& Hart RE (2018) Astonishing diversity-the medicinal plant markets of Bogotá, Colombia. Journal of Ethnobiology and Ethnomedicine 14: 1-47.

Byrne MJ, Williams VL \& Wojtasik EM (2017) The viability of propagules of alien plant species sold for traditional medicine in South Africa. South African Journal of Botany 109: 281-287.

Cagnotti C, Mc Kay F \& Gandolfo D (2007) Biology and host specificity of Plectonycha correntina Lacordaire (Chrysomelidae), a candidate for the biological control of Anredera cordifolia (Tenore) Steenis (Basellaceae). African Entomology 15: 300-309.

Chao P, Lin S, Lin K, Liu Y, Hsu J, Yang C \& Lai J (2014) Antioxidant activity in extracts of 27 indigenous Taiwanese vegetables. Nutrients 6: 2115-2130.

Chuang M, Lin Y \& Hou W (2007) Ancordin, the major rhizome protein of madeira-vine, with trypsin inhibitory and stimulatory activities in nitric oxide productions. Peptides 28: 1311-1316.

Djamil R (2012) Antioxidant activity of flavonoid from Anredera cordifolia (Ten) Steenis leaves. International Journal of Pharmacy 3: 241-243. 
Djamil R, Winarti W, Zaidan S \& Abdillah S (2017) Antidiabetic activity of flavonoid from binahong leaves (Anredera cordifolia) extract in alloxan induced mice. Journal of Pharmacognosy \& Natural Products 03: 2-5.

Downey PO, Scanlon TJ \& Hosking JR (2010) Prioritizing weed species based on their threat and ability to impact on biodiversity: a case study from New South Wales. Plant Protection Quarterly 25: 111-126.

Ekaviantiwi TA, Fachriyah E \& Kusrini D (2013) Identification of phenolic acid from ethanolic extract of binahong (Anredera cordifolia (Ten.) Stennis) leaves and antioxidant activity. Chem Info 1: 283-293.

Elya B, Handayani R, Sauriasari R, Azizahwati, Hasyyati US, Permana IT \& Permatasari YI (2015) Antidiabetic activity and phytochemical screening of extracts from indonesian plants by inhibition of alpha amylase, alpha glucosidase and dipeptidyl peptidase IV. Pakistan Journal of Biological Sciences 18: 273-278.

Erikson R (2007) A synopsis of Basellaceae. Kew Bulletin 62: 297-320.

Fitriana WD, Istiqomah SBT, Ersam T \& Fatmawati S (2018) The relationship of secondary metabolites: A study of Indonesian traditional herbal medicine (Jamu) for post partum maternal care use. AIP Conference Proceedings 2049: 020096-1-8.

Floyd AG (1989) The vine weeds of coastal rainforest. Proceedings of the 5th Biennial Noxious Plants Conference, Sydney. Avaliable at $<$ http:// www.nswweedsoc.org.au/conferences/past_ proceedings/>. Access on 15 May 2019.

Gao L, Hou B, Cai ML, Zhai JJ, Li WH \& Peng CL (2018) General laws of biological invasion based on the sampling of invasive plants in China and the United States. Global Ecology and Conservation 16: 1-14.

Garmana AN, Sukandar EY \& Fidrianny I (2016) Preliminary study of blood pressure lowering effect of Anredera cordifolia (Ten.) Steenis on Wistar rats. International Journal of Pharmacognosy and Phytochemical Research 8: 300-304.

Garmana AN, Sukandar EY \& Fidriannya I (2014) Activity of several plant extracts against drugsensitive and drug-resistant microbes. Procedia Chemistry 13: 164-169.

Haitan Z, Jianping T, Lian W, Juan Z, Yuping W, Ze H \& Qingxuem G (2011) Influences of herbaceous vines on community characteristics in pioneer succession stages. Acta Ecologica Sinica 31: 186-191.

Heinzmann BM \& Barros FMC (2007) Potencial das plantas nativas brasileiras para o desenvolvimento de fitomedicamentos tendo como exemplo Lippia alba (Mill.) N.E. Brown (Verbenaceae). Saúde (Santa Maria) 33: 43-48.

Heisler EV, Badke MR, Andrade A \& Rodrigues MGS (2012) Popular knowledge about the use of plant
Anredera cordifolia (Fat Leaf). Texto \& Contexto Enfermagem 21: 937-944.

Hendriani R \& Sukandar EY (2016) In vitro evaluation of xanthine oxidase inhibitory activity of selected medicinal plants. International Journal of Pharmaceutical and Clinical Research 8: 235-238.

Hilgert NI (2001) Plants used in home medicine in the Zenta River basin, Northwest Argentina. Journal of Ethnopharmacology 76: 11-34.

Imig DC, Nunes MG \& Engels ME (2015) The genus Anredera (Basellaceae) in Paraná state, Brazil. Acta Biológica Paranaense 44: 17-24.

Istyastono EP \& Yuliani SH (2016) Scarless wound healing gel with binahong (Anredera cordifolia (Ten) Steenis) leaves extract and celecoxib as the active ingredients. AIP Conference Proceedings 160001: 1-6.

Jian O, Changyi L \& Desmond KO (2008) A risk assessment system for alien plant bio-invasion in Xiamen, China. Journal of Environmental Sciences 20: 989-997.

Kaunang ENS \& Semuel MY (2017) Botanical and phytochemical constituents of several medicinal plants from mount Klabat north Minahasa. Journal of Medicinal Plants Studies 5: 29-35.

Kelen MEB, Nouhuys ISV, Kehl LCK, Brack P \& Silva DB (2015) Plantas alimentícias não convencionais (Panc) no Brasil. UFRGS Ed., Porto Alegre. Avaliable at <https://www.ufrgs.br/ viveiroscomunitarios/wp-content/uploads/2015/11/ Cartilha-15.11-online.pdf $>$ Access on 12 May 2019.

Kintoko \& Desmayanti A (2016) The effectivity of ethanolic extract of binahong leaves (Anredera cordifolia (Tenore) Steen) gel in the management of diabetic wound healing in aloxan-induced rat models. Jurnal Kedokteran Dan Kesehatan Indonesia 7: 227-236.

Kinupp VF, Amaro FS \& Barros IBI (2004) Anredera cordifolia (Basellaceae), uma hortaliça potencial em desuso no Brasil. Horticultura Brasileira 22: 346.

Kinupp VF \& Lorenzi H (2014) Plantas alimentícias não convencionais (PANC) no Brasil: guia de identificação, aspectos nutricionais e receitas ilustradas. Instituto Plantarum, São Paulo. 768p.

Kumalasari E \& Sulistyani N (2011) Antifungal activity of ethanol extract of binahong stem (Anredera cordifolia (Tenore) Steenis) against Candida albicans and the phytochemical screening. Pharmaciana 1: 51-62.

Laksmitawati DR, Widyastuti A, Karami N, Afifah E, Rihibiha DD, Nufus H \& Widowati W (2017) Anti-inflammatory effects of Anredera cordifolia and Piper crocatum extracts on lipopolysaccharidestimulated macrophage cell line. Bangladesh Journal of Pharmacology 12: 35-40.

Lestari D, Sukandar EY \& Fidrianny I (2015) Anredera cordifolia leaves extract as antihyperlipidemia and endothelial fat content reducer in male wistar rat. 
International Journal of Pharmaceutical and Clinical Research 7: 435-439.

Lestari D, Sukandar EY \& Fidrianny I (2016) Anredera cordifolia leaves extract as antihyperlipidemia. International Journal of Pharmaceutical and Clinical Research 9: 82-84.

Lin H, Kuo S-C, Chao P-DL \& Lin T-D (1988) A new sapogenin from Boussingaultia gracilis. Journal of Natural Products 51: 797-798.

Magwede K, Van Wyk BE \& Van Wyk AE (2018) An inventory of Vhavenda useful plants. South African Journal of Botany 122: 57-89.

Maharani ES, Puspitawati R \& Gunawan HA (2018) Antibacterial effect of binahong (Anredera cordifolia (Ten.) Steenis) leaf infusion against black pigmented bacteria. Journal of Physics: conference series 1073: 1-6.

Marin-Felix Y, Hernández-Restrepo M, Wingfield MJ, Akulov A, Carnegie AJ, Cheewangkoon R \& Crous PW (2019) Genera of phytopathogenic fungi: GOPHY 2. Studies in Mycology 92: 47-133.

Martinevski CS, Oliveira VR \& Flores SH (2013) Use of bertalha Anredera cordifolia (Ten) in making bread. Brazilian Journal of Food and Nutrition 24: 3-8.

Miladiyah I \& Prabowo BR (2012) Ethanolic extract of Anredera cordifolia (Ten.) Steenis leaves improved wound healing in guinea pigs. Universa Medica 31: 4-11.

Mogale MMP, Raimondo DC \& VanWyk BE (2019) The ethnobotany of Central Sekhukhuneland, South Africa. South African Journal of Botany 122: 1-550.

Mulaudzi RB, Ndhlala AR \& Van Staden J (2015) Ethnopharmacological evaluation of a traditional herbal remedy used to treat gonorrhoea in Limpopo province, South Africa. South African Journal of Botany 97: 117-122. doi: < https://doi.org/10.1016/j. sajb.2014.12.007>

Mulia K, Muhammad F \& Krisanti E (2017) Extraction of vitexin from binahong (Anredera cordifolia (Ten.) Steenis) leaves using betaine - 1, 4 butanediol natural deep eutectic solvent (NADES). AIP Conference Proceedings 020018: 1-4.

Nazliniwaty N, Suryanto S \& Damanik DD (2018) The utilization of binahong (Anredera cordifolia (Ten.) Steenis) leaf as an anti-aging. Asian Journal of Pharmaceutical and Clinical Research 11: 87- 89.

Oliveira FQ, Gobira B, Guimarães C, Batista J, Barreto M \& Souza M (2007) Espécies vegetais indicadas na odontologia. Brazilian Journal of Pharmacognosy 17: 466-476.

OMS (2013) Estrategia de la OMS sobre medicina tradicional 2014-2023. In Organización Mundial de la Salud. Avaliable at <https://www.who.int/ topics/traditional_medicine/WHO-strategy/ es/>. Access on 13 May 2019.

Paccard E (1905) Lista de algunas plantas medicinales de las Repúblicas Oriental y Argentina. Ed. Talles A. Barreiro Y Ramos, Calle Cerro. 111p.
Paju N, Yamlean PVY \& Kojong N (2013) Test the effectiveness of Binahong leaf extract ointment (Anredera cordifolia (Ten.) Steenis) in rabbits (Oryctolagus cuniculus) infected with bacteria Staphylococcus aureus. Pharmacon Jurnal Ilmiah Farmasi - UNSRAT 2: 2302-2493.

Palmer WA, Heard TA \& Sheppard AW (2010) A review of Australian classical biological control of weeds programs and research activities over the past 12 years. Biological Control 52: 271-287.

Panyaphu K, On TV, Sirisa-ard P, Srisa-nga P \& Chansakaow S (2011) Medicinal plants of the Mien (Yao) in Northern Thailand and their potential value in the primary healthcare of postpartum women. Journal of Ethnopharmacology 135: 226-237.

Paz EA, Cerdeiras MP, Fernandez J, Ferreira F, Moyna P, Soubes M \& Zunino L (1995) Screening of Uruguayan medicinal plants for antimicrobial activity. Journal of Ethnopharmacology 45: 67-70.

Pellegrini MOO \& Imig D (2019) Basellaceae. In: Flora do Brasil 2020 em construção. Instituto de Pesquisas Jardim Botânico do Rio de Janeiro. Avaliable at $<$ http://reflora.jbrj.gov.br/reflora/listaBrasil/ FichaPublicaTaxonUC/FichaPublicaTaxonUC. do? $\mathrm{id}=$ FB5557 $>$. Access on 09 May 2019.

Pellegrini MOO \& Sakuragui CM (2017) Flora do Espírito Santo: Basellaceae. Rodriguésia 68: 15411545.

Pintó-Marijuan M \& Munné-Bosch S (2013) Ecophysiology of invasive plants: osmotic adjustment and antioxidants. Trends in Plant Science 18: 660-666.

Pitaloka DAE \& Sukandar EY (2018) Synergistic study on n-hexane extract of Anredera cordifolia (Ten.) Steenis (binahong) leaves combined with antituberculosis drugs against drug-sensitive and drug-resistant of Mycobacterium tuberculosis. Journal of Applied Pharmaceutical Science 8: 134-138.

Prasetyo AT \& Herihadi E (2013) The application of moist exposed burn ointment (MEBO) and binahong leaves in treating partial thickness burn: a case report. Jurnal Plastik Rekonstruksi 3: 142-146.

Prastowo J, Herawati O \& Ariyadi B (2017) Effects of Areca catechu seed and Anredera cordifolia leaf on Ascaridia galli infection in the domestic chicken (Gallus gallus domesticus). International Journal of Poultry Science 16: 494-499.

Rahmawati F \& Bintari SH (2014) Activities study of antibacterial of binahong leaf (Anredera cordifolia) on growth Bacillus cereus and Salmonella enteritidis. Unnes Journal of Life Science 3: 130-138.

Rahmawati L, Fachriyah E \& Kusrini D (2013) Insulation, identification and test of antioxidant activities leaves flavonoid compounds (Anredera cordifolia (Ten.) Steenis). Chem Info 1: 1-10.

Rasingam L \& Lakshminarasimhan P (2012) Anredera cordifolia (Basellaceae) - an addition to the nonindigenous flora of India. Rheedea 22: 16-17. 
Rimporok S, Kepel BJ \& Siagian KV (2015) Effectiveness of binahong leaf extract (Anredera cordifolia Steenis) on the growth of in vitro Streptococcus mutans. Pharmacon Jurnal Ilmiah Farmasi - Unsrat 4: 15-21.

Salasanti CD, Sukandar EY \& Fidrianny I (2014) Acute and sub chronic toxicity study of ethanol extract of Anredera cordifolia (Ten.) Steenis leaves. International Journal of Pharmacy and Pharmaceutical Sciences 6: 348-352.

Scarpa GF (2004) Medicinal plants used by the Criollos of Northwestern Argentine Chaco. Journal of Ethnopharmacology 91: 115-135.

Shen S, Day MD, Xu G, Li D, Jin G, Yin X \& Winston RL (2018) The current status of biological control of weeds in southern China and future options. Acta Ecologica Sinica 38: 157-164.

Shen S, Xu G, Li D, Clements DR, Jin G, Yin X \& Zhang F (2017) Occurrence and damage of invasive alien plants in Dehong Prefecture, western of Yunnan Province. Acta Ecologica Sinica 37: 195-200.

Shrivastav A, Mishra AK, Ali SS, Ahmad A, Abuzinadah MF \& Khan NA (2018) In vivo models for assesment of wound healing potential: a systematic review. Wound Medicine 20: 43-53.

Silva V, Figueiredo E, Smith GF (2015) Alien succulents naturalised and cultivated on the central west coast of Portugal. Bradleya 33: 58-81.

Souza LF, Barros IBI, Mancini E, Martino L, Scandolera E \& Feo V (2014) Chemical composition and biological activities of the essential oil from Anredera cordifolia grown in Brazil. Natural Product Communications 9: 1003-1006.

Souza VC \& Lorenzi H (2012) Botânica Sistemática: guia ilustrado para identificação das famílias de fanerógamas nativas e exóticas do Brasil. $3^{\mathrm{a}}$ ed. Instituto Plantarum, São Paulo. 531p.

Srithi K, Trisonthi C, Wangpakapattanawong P \& Balslev H (2012) Medicinal plants used in Hmong women's healthcare in northern Thailand. Journal of Ethnopharmacology 139: 119-135. <https://doi. org/10.1016/j.jep.2011.10.028>

Stehmann JR \& Sobral M (2017) Biodiversidade no Brasil. In: Simões CMO, Schenkel EP, Mello JCP, Mentz LA \& Petrovick PR (eds.) Farmacognosia: do produto natural ao medicamento. Artmed, Porto Alegre. Pp. 1-8.

Sukandar EY, Fidrianny I \& Adiwibowo LF (2011) Efficacy of ethanol extract of Anredera cordifolia (Ten) Steenis leaves on improving kidney faluire in rats. International Journal of Pharmacology 7 : 850-851.

Sukandar EY, Kurniati NF \& Fitria V (2014) Evaluation of teratogenicity effects of ethanolic extracts of binahong leaves (Anredera cordifolia (Ten) Steenis) in wistar rat. International Journal of Pharmacy and Pharmaceutical Sciences 6: 422-426.
Sukandar EY, Kurniati NF \& Nurdianti AN (2016a) Antiobesity effect of ethanol extract of Anredera cordifolia (Ten) Steenis leaves on obese male wistar rats induced by high-carbohydrate diet. International Journal of Pharmacy and Pharmaceutical Sciences 8: 171-173c.

Sukandar EY, Ridwan A \& Sukmawan YP (2016b) Vasodilatation effect of ethanolic extract of Anredera cordifolia, Sonchus arvensis L., and Ursolic acid on isolated rabbit aortic and frog heart. International Journal of Pharmacy and Pharmaceutical Sciences 8: 145-149a.

Sukandar EY, Safitri D \& Aini NN (2016c) Thes study of ethanolic extract of binahong leaves (Anredera cordifolia (Ten.) Steenis) and mulberry leaves (Morus nigra L.) in combination on hyperlipidemic induced rats. Asian Journal of Pharmaceutical and Clinical Research 9: 288-292b.

Sukandar EY, Sigit JI \& Adiwibowo LF (2013) Study of kidney repair mechanisms of corn silk (Zea mays L. hair) - binahong (Anredera cordifolia (Ten.) Steenis) leaves combination in rat model of kidney failure. International Journal of Pharmacognosy and Phytochemical Research 9: 12-23.

Sumartiningsih S (2011) The effect of Binahong to hematoma. International Journal of Medical and Health Sciences 5: 244-246.

Sutrisno E, Adnyana IK, Sukandar EY, Fidrianny I \& Aligita W (2016) Anti-inflammatory study of Anredera cordifolia leaves and Centella asiatica herbs and its combinations using human red blood cell-membrane stabilization method. Asian Journal of Pharmaceutical and Clinical Research 9: 78-80.

Tshikalange TE, Meyer JJM \& Hussein AA (2005) Antimicrobial activity, toxicity and the isolation of a bioactive compound from plants used to treat sexually transmitted diseases. Journal of Ethnopharmacology 96: 515-519.

Van Driesche RG, Carruthers RI, Center T, Hoddle MS, Hough-Goldstein J, Morin L \& van Klinken RD (2010) Classical biological control for the protection of natural ecosystems. Biological Control 54: S2-S33.

Veiga Junior VFV, Pinto AC \& Maciel MAM (2005) Plantas medicinais: cura segura? Quimica Nova 28: 519-528.

Vivian-Smith G, Lawson BE, Turnbull I, Paul O, Management RS, Council BS \& Division W (2007) The biology of Australian weeds 46. Plant Protection Quarterly 22: 2-10.

Waryszak P, Lenz TI, Leishman MR \& Downey PO (2018) Herbicide effectiveness in controlling invasive plants under elevated $\mathrm{CO}_{2}$ : sufficient evidence to rethink weeds management. Journal of Environmental Management 226: 400-407.

Westhuizen LV (2011) Initiation of a biological control programme against madeira vine, Anredera 
cordifolia (Ten.) Steenis (Basellaceae), in South Africa. African Entomology 19: 217-222.

Widyarini KD, Sukandar EY \& Fidrianny I (2015) Xanthine oxidase inhibitory and antihyperuricemic activities of Anredera cordifolia (Ten) Steenis, Sonchus arvensis L., and its combination. International Journal of Pharmacy and Pharmaceutical Sciences 7: 86-90.

Wijayanti D, Setiatin ET \& Kurnianto E (2017) Study on postpartum estrus of guinea pigs (Cavia cobaya) using Anredera cordifolia leaf extract. Veterinary World 10: 375-379.

Wijayanti Dwi, Setiatin ET \& Kurnianto E (2016) The effect of Binahong (Anredera cordifolia (Ten) Steenis) on the erythrocyte profiles of ginea pigs (Cavia cobaya). Jurnal Sain Veteriner 34: 75-83.

Xifreda C, Argimón S \& Wulff AF (2000) Infraspecific characterization and chromosome numbers in Anredera cordifolia (Basellaceae). Thaiszia Journal of Botany 9: 99-108.

Yan L, Iwan Y, Hening H \& Hendarti T (2011) Inhibition effect of Binahong (Anredera Cordifolia (Ten.) Steenis) leaf extract towards polybacteria of recurrent ap. Research Report Oral 3: 18-26.

Yang RY, Lin S \& Kuo G (2008) Content and distribution of flavonoids among 91 edible plant species. Asia Pacific Journal of Clinical Nutrition 17: 275-279.

Yen GC, Chen HY \& Peng HH (2001) Evaluation of the cytotoxicity, mutagenicity and antimutagenicity of emerging edible plants. Food and Chemical Toxicology 39: 1045-1053.
Yuliani SRIH, Anggraeni CD, Sekarjati W, Panjalu A, Istyastono EP \& Setiawati A (2015) Cytotoxic activity of Anredera cordifolia leaf extract on hela cervical cancer cells through $\mathrm{p}$ 53-independent pathway. Asian Journal of Pharmaceutical and Clinical Research 8: 328-331.

Yuliani SH \& Istyastono EP (2013) Factorial design application to study ursolic acid extraction process from Binahong (Anredera cordifolia (Ten) Steenis). Medicinus 26: 35-39.

Yuziani, Harahap U \& Karsono (2014) Evaluation of analgesic activities of ethanolic extract of Anredera cordifolia (Ten) Steenis leaf. International Journal of PharmTech Research 6: 1608-1610.

Zank S \& Hanazaki N (2012) Exploring the links between ethnobotany, local therapeutic practices, and protected areas in Santa Catarina coastline, Brazil. Evidence-Based Complementary and Alternative Medicine 2012: 1-15.

Zhu J, Wang J, DiTommaso A, Zhang C, Zheng G, Liang W \& Zhou W (2018) Weed research status, challenges, and opportunities in China. Avaliable at <https://www.researchgate.net/ publication/323553692 Weed research status challenges_and_opportunities_in_China $>$. Acess on 02 June 2019.

Zulfa E, Prasetyo TB \& Murrukmihadi M (2017) Antibacterial activity test of ointment ethanolic extract of binahong leaf (Anredera cordifolia (Ten.) Steenis) with various base variations on Staphylococcus aureus bacteria. Jurnal Pharmascience 4: 18-24. 